\title{
Problems of Disputes/Conflicts over Land Acquisition towards Development for Public Interest in Indonesia
}

\author{
Rofi Wahanisa ${ }^{1, *}$, Arif Hidayat ${ }^{2}$, R. Benny Riyanto ${ }^{2}$ and Bayu Dwi Anggono ${ }^{3}$ \\ ${ }^{1}$ Faculty of Law, Universitas Negeri Semarang (UNNES), Indonesia; ${ }^{2}$ Faculty of Law, Diponegoro University, \\ Semarang, Indonesia; ${ }^{3}$ Faculty of Law, Jember University, Indonesia
}

\begin{abstract}
The issue that will be discussed in this paper are problems causing disputes/conflicts over land acquisition toward development for the public interest. To address those problems, document and literature search as well as literature review are employed, including the cases of land acquisition that have occurred to be analyzed descriptively to achieve resolution to the problems. The results showed that land acquisition is closely related to eviction, land purchase, compensation, repressive actions of the apparatus, public reluctance to move from the acquired land, and public refusal towards the form and amount of the compensation. The problems due to land acquisition that provokes disputes/conflicts arise from three sources: a substance (in terms of regulations, or biased meaning of public interest), structure (the roles of officials/institutions related to land acquisition), and public. Regarding the fact that the existence of disputes/conflicts over land acquisition is frequently related to the issue of justice and public welfare, therefore, attention and efforts are practically needed to achieve justice and welfare, especially for those whose lands are acquired without ignoring the aspect of legal certainty as a characteristic of state law.
\end{abstract}

Keywords: Land disputes/conflicts, land acquisition, public interest, Indonesia.

\section{INTRODUCTION}

Indonesia is a welfare rechtsstaat concerning the fourth paragraph of the 1945 Constitution of the Republic of Indonesia (hereinafter referring to the 1945 Constitution) stating "shall protect the whole people of Indonesia and the entire homeland of Indonesia, and to advance general prosperity, to develop the nation's intellectual life, and to contribute to the implementation of a world order based on freedom, lasting peace and social justice". From those national goals, it can be said that Indonesia is considered as a welfare rechtsstaat despite different concepts between rechsstaat and welfare state that practically become entity (Erwiningsih, 2009).

Land acquisition is a means of achieving welfare through development. The need for land is an inevitable part of development as the nation requires land for the development. Unfortunately, it is realized that the availability of land with the status of "free" state land is very limited. Therefore, it provokes logical consequence that is nation's attempts to provide land for development by gaining control of public's land labeled with individual interest - land owned by public or customary law community. The existence of two parties - the nation (government interest) as the one requiring land on the one hand and public interest on the other hand - frequently prompts disputes/conflicts over land acquisition activity.

*Address correspondence to this author at the Faculty of Law, Universitas Negeri Semarang (UNNES). Gunung Pati, Semarang, Central Java 50229, Indonesia; Tel/Fax: (024) 8507891; E-mail: rofiwahanisa@mail.unnes.ac.id
Land acquisition as a means of providing land for development of public interest carried out by the nation is a construction of the Nation's Control Right (HMN) in the Article 2 (2) of the 1960 Basic Agrarian Law No. 5 (hereinafter referring to UUPA), stating that the nation has authority to control and manage land use extensively for public welfare as stated in the Article 33 (3) of the 1945 Constitution. Article 18 of the Basic Agrarian Law (UUPA) provides a legal principle for the "acquisition" of land rights by the nation for the public interest; including national and common interest, revoking land rights by giving appropriate and fair compensation according to the procedures regulated in the Constitution. The Article 6 of the Basic Agrarian Law states that all land right has social functions. In other words, land right not only means freehold estate but also a social function. In this article, it is explained that one's land right is not justifiable that the land will (will not) be used solely for his/her personal interest, particularly if it causes public loss.

Meanwhile, the Article $28 \mathrm{H}$ (4) of the 1945 Constitution guarantees, "every person has personal freehold estate, and it cannot be taken arbitrarily by anyone." This Article contains respect for personal rights by the nation in terms of freehold estate on land. Therefore, land acquisition for development over land owned by the public must not be carried out arbitrarily. However, in retaining their right and freedom, every person must comply with the limitation set by the Constitution to solely assure recognition and respect over right and freedom of others and to meet fair demand based on moral consideration, religious 
values, security, and public order in a democratic society.

\section{RESULTS}

Land dispute refers to dispute over land between individuals, legal entities, or institutions that sociopolitically create inconsiderable impact. The emphasis lying on inconsiderable impact differentiates the definition of land dispute from that of land conflict. According to Wiradi (2009), dispute refers to the one arising due to a conflict of interest over land. Conflict, which is generally considered to be similar to a dispute, in fact, can be defined from its root. Conflict and Dispute (Konflik dan Sengketa in the Indonesian language) are derived from English words conflict and dispute - both means a disagreement between two or more parties. The difference, on the contrary, lies in the fact a conflict cannot lead to a dispute if the party suffering loss does not show dissatisfaction or concern (Usman, 2003).

A high proportion of disputes/conflicts based on the data published by the Agrarian Reform Consortium (KPA) in 2014 occurred in infrastructure projects. The Agrarian Reform Consortium (KPA) recorded at least there were 215 agrarian conflicts $(45.55 \%)$ in this sector, and it is shown in the following Table 1.

Table 1: Number of Agrarian Conflicts by Sector 2014

\begin{tabular}{|c|c|c|}
\hline No & Sector & Total \\
\hline \hline 1 & Infrastructure & $215(45.55 \%)$ \\
\hline 2 & Plantation & $185(39.19 \%)$ \\
\hline 3 & Forestry & $27(5.72 \%)$ \\
\hline 4 & Agriculture & $20(4.24 \%)$ \\
\hline 5 & Mining & $14(2.97 \%)$ \\
\hline 6 & Water and marine & $4(0.85 \%)$ \\
\hline 7 & Others & $7(1.48 \%)$ \\
\hline
\end{tabular}

Source: Agrarian Reform Consortium, 2014.

Development of this infrastructure includes development activities to provide land for public interest through a land acquisition mechanism. Moreover, plantation expansion takes the second position with 185 agrarian conflicts (39.19\%) followed by the forestry sector with 27 conflicts (5.72\%), the agriculture sector with 20 conflicts $(4.24 \%)$, the mining sector with 14 conflicts $(2.97 \%)$, waters and marine sector with 4 conflicts $(0.85 \%)$, and other sectors with 7 conflicts (1.48\%). Compared to that of 2013, a significant rise of conflicts occurred as many as 103 conflicts (27.9\%).
Also, in 2016 data from the Agrarian Reform Consortium (KPA) showed that dispute/conflict in the infrastructure sector stood in the third position with 110 cases $(22.22 \%)$ after the property sector, and the proportion is displayed in the following Table $\mathbf{2}$.

Table 2: Number of Agrarian Conflicts 2016

\begin{tabular}{|c|c|c|}
\hline No & Sector & Total \\
\hline \hline 1 & Plantation & $163(36.22 \%)$ \\
\hline 2 & Property & $117(26.00 \%)$ \\
\hline 3 & Infrastructure & $100(22.22 \%)$ \\
\hline 4 & Forestry & $25(5.56 \%)$ \\
\hline 5 & Mining & $21(4.67 \%)$ \\
\hline 6 & Coastal and marine & $10(2.22 \%)$ \\
\hline 7 & Oil and Gas & $7(1.56 \%)$ \\
\hline 8 & Agriculture & $7(1.56 \%)$ \\
\hline
\end{tabular}

Source: Agrarian Reform Consortium, 2016.

Plantation still becomes the sector in which agrarian conflict most frequently occurred with 163 cases $(36.22 \%)$, followed by the property sector with 117 cases $(26.00 \%)$, and the infrastructure sector with 100 cases $(22.22 \%)$. Moreover, there were 25 cases (5.56) in the forestry sector, 21 cases $(4.67 \%)$ in the mining sector, 10 cases $(2.22 \%)$ in the coastal and marine sector, and 7 cases (1.56\%) in oil, gas, and agriculture sector (Agrarian Reform Consortium, 2016).

Then, in 2017 the data of dispute/conflict frequency presented that the plantation sector still takes first place with 208 cases (32\%). The property sector was in second place with 199 cases $(30 \%)$. The infrastructure sector stood in the third position with 94 cases $(14 \%)$, followed by the agriculture sector with 78 cases $(12 \%)$, the forestry sector with 30 cases $(5 \%)$, coastal and marine sector with 28 cases $(4 \%)$, and finally mining sector with 22 cases (3\%). In conclusion, within three years of Jokowi-JK leadership, 1.361 agrarian conflicts occurred(Agrarian Reform Consortium, 2017). According to the annual report of the Agrarian Report Consortium, the property sector took second place followed by the infrastructure sector in third place.

\section{MEANING OF PUBLIC INTEREST}

Legislation regulating land acquisition for the development of public interest has been repeatedly changing from the Old Order era, New Order era, to the reform era. The changes frequently or even always provoke debate over the definition of public interest. Public interest is a term that seems to be easily 
understood but difficult to be explained in words/ in terms of the definition of the language grammar. In the Old Order era when the Constitution No. 20 of 1961 on Revocation of Right of Land and the Above Objects was employed, public interest was explained as follows "for a public interest, including national and common interest, as well as development interest, the President in an emergency state after listening to the consideration from the agrarian minister, justice minister, and another related minister can revoke the right of land and the above objects" (Article 1 of the Constitution No. 20 of 1961).

In the New Order era, as regulated in the Presidential Instruction (Inpres) No. 9 of 1973, public interest consisted of several definitions. First, an activity for implementing development contained public interest concern if it embraced national interest and/or common interest and/or development interest. Second, development activity with public interest concern involved several sectors such as defense, public works, public facilities, public services, religion, science, art, and culture, health, sport, public safety towards natural disasters, social welfare, cemetery, tourism, and recreation, and economic works that were beneficial for public welfare. The President could determine other forms of development that based on his consideration were needed for the public interest.

Third, a development project was said to have public interest concern if it had been embraced in the Development Plan informed to the concerned society. If a Regional Development project was set to have public interest concern, it previously had to be included in the Development Master Plan of the concerned region and approved by the Regional Legislative Councils. The Master Plan of the Development must be open to the public. Fourth, the President had the authority to revoke land rights, and fifth, Institution/ Government Agency or private business was authorized to be the subject or applicant of land right revocation by considering the requirements of gaining land right according to the existing regulations. The project plan of private business had to be approved by the Government and/or Regional Government based on the existing Development Plan

Moreover, the replacement of Presidential Instruction No. 9 of 1973 with the Home Affairs Ministry Regulation (Permendagri) No. 15 of 1975, the definition of public interest as a means of land acquisition was not formulated. However, the implementation of this regulation implied that land acquisition was carried out to meet the need of development by the institution, government agency, or private interest. Based on the phrase "considering", the meaning of public interest in the Home Affairs Ministry Regulation was identical to development interest carried out by both the Government and private parties. The authority of land acquisition was given to the Committee of Land Acquisition formed by the Governor, but the form and requirements of development activity underlying land acquisition were not determined.

Then, the Home Affairs Ministry Regulation was replaced with Presidential Decree No. 55 of 1993 in which the definition of public interest refers to the interest of all levels of the society carried out and owned by the Government for non-profit purposes. Forms of activity with public interest concern comprised 14 fields: (a) public road and drainage; (b) reservoir, dam, and irrigation structure including irrigation canal; (c) public hospital and health center; (d) port, airport, or station; (e) worship; (f) education and school; (g) public and Inpres market, (h) public cemetery; (i) public safety such as disaster mitigation; (j) post and telecommunication; (k) sports facility; (I) radio broadcasting station, television, and its supporting facility; (m) government office; ( $n$ ) Indonesian armed force facility; and other activities stated by the Presidential Decree.

In the reform era, the regulation of land acquisition was recharged in the Presidential Regulation No. 36 of 2005. In this regulation, there was no limitation of the definition of public interest - mentioned as the interest of most of the social levels. In this regulation, there were also additional items regarding the criteria of activity included as public interest from 14 items (in the Presidential Decree) to 21 items. Meanwhile, in the Presidential Regulation No. 65 of 2006 on Changes on the Presidential Regulation No. 36 of 2005 on Land Acquisition towards Development for Public Interest, it was stated that there was a limitation of the criteria of public interest - different from the previous regulation in terms of adding "will" be owned and eliminating "used for a non-profit purpose". Article 5 determined the criteria of activity regarded as the public interest. Therefore, according to Article 5, the object of public interest consisted of: a. public road and the toll road, railway (above the ground, on the ground, or underground), drinking/ clean water canal, drainage, and sanitation; b. reservoir, dam, irrigation dam, and other irrigation structures; c. port, airport, railway station, and bus station; $d$. public safety facility such as embankment for mitigating floods, lava, and other 
natural disasters; e. garbage dump; f. nature and culture preserve; $g$. the power plant, power transmission, and power distribution.

The provision of this presidential decree was then replaced with Constitution No. 2 of 2012 by embracing the definition of public interest that is national and common interest used greatly for public welfare.

Public interest, according to Rousseau (1997), is an individual right given to the authorities to be carried out including the right to live peacefully, right of the order, and right of law protection. Public interest refers to the common interest which cannot be carried out individually (Von Schmid, 1954). Van Wijk (1976) notion on public interest is a public lawsuit that must be served by the Government to achieve public welfare. On the other side, Poerbopranoto (1987) asserts that public interest involves national and common interest. It resolves individual, group, and regional interests.

Notonagoro (1988) claims that despite the fact public interest can resolve individual interest, it does not mean that the nation does not acknowledge individual interest. Personal interest is included in public interest relying on social justice. In terms of land acquisition for a public interest, the definition of public interest has been extracted in the Basic Agrarian Law (UUPA) in the sentence "for public interest including national and common interest, the land right can be revoked by giving appropriate compensation.

Due to difficulty to achieve an agreed-upon definition of public interest, several methods are commonly used (Sumardjono, 2008). First, the General Guide states that land acquisition must rely on public interest concerns. Thus, it gives the executive authority to determine whether a project is eligible as public interest by interpreting the guide. Second, List Provisions mentions an interest in a list of activities that identifies its goal that is considered beneficial for the public according to the legislation. Activity that is out of the list cannot be used as a basis for land acquisition.

Semantic complexity in defining public interest interpreted differently by individuals often leads to problems in carrying out the land acquisition. A facility developed using the mechanism of land acquisition is not always considered as public interest so that the owner is reluctant to give the land.

\section{DISCUSSION}

The problem in dispute/conflict of land acquisition also possibly arises from structural components.
According to Friedman (1975), a structural component refers to institutions established by the legal system to support the legal system. These structural components allow service and regular legal enforcement. It is a structural factor that determines whether the law can be well-enforced. The Authority of law enforcement institutions is guaranteed by the Constitution so that they can carry out their duties and responsibilities regardless of the government power and other influence.

Law cannot be enforced if no apparatus is credible, competent, and independent. Moreover, justice cannot be achieved if good legislation is not supported by good law enforcement. The weak mentality of the law enforcement officer leads to a lack of proper law implementation.

In some cases of land acquisition, conflict of interest occurred between the institutions that served functions to execute land acquisition and resolve dispute/conflict. For instance, the Project of Yogyakarta Highway showed disorganized regulations of land administration that prompted conflict of land ownership. As a result, determining the rightful party took a long time and finally leads to bureaucratic regulations that are practically inefficient. It seems paradoxical that the existence of regulations is supposed to make an activity efficient, yet its application provokes problems due to disagreement over the regulations. To the same extent, the construction of Toll Road in Kendal Regency brings problems regarding mall administration and the amount of compensation. Intimidation and pressure from the executor and an indication of mark up over the compensation object was found, and in some villages rejection from the society arose regarding the execution of court ruling of consignment results.

The roles of the apparatus regarding land acquisition cause dispute/conflict as on the one hand they serve the function to "succeed" the development of public facility (part of the nation), on the other hand, they are assigned to resolve dispute/conflict if the society is reluctant to give their land as part of land acquisition. As notion in his theory of conflict, the legal structure of land acquisition and dispute resolution for the public interest is highly influenced by government interest as the representation of the nation(Ritzer \&Stepnisky, 2017).

The next problem arising in land acquisition deals with the form and amount of compensations in which it 
begins with public reluctance to give their land to be included in the development plan. It is due to a lack of information regarding the plan of land acquisition that will be applied and the "historical" bond between the owners and their land. The land is a source of life in terms of human life. Conflict over land means conflict over food, pillars of human life so that people can shed blood and sacrifices everything to survive (Tauchid, 2011). The Article 6 of the Basic Agrarian Law No. 5 of 1960 states that land has a social function that equally balances individual interest and public interest.

In addition to the historical relationship with the land, public reluctance to hand over their land is caused by the "appreciation" value which refers to "unfair" compensation based on their expectation. Compensation is a very sensitive thing due to its role in "valuing" land price in which the landowner might have an inner relationship with the land - such as ancestral land, waqf land, cemetery, inherited land, etc. The Article 33 of the Constitution No. 22 of 2012 on Land Acquisition toward Development for Public Interest state that valuing the amount of the compensation is assessor's job that consists of a) land, b) above and under space of the land, c) building, d) plants, e) things related to the land and/or, f) other loss that can be valued.

Also, in Article 36 of the Constitution No. 2 of 2012, compensation can be given in the form of a) money, b) land in exchange, c) new settlement, d) share ownership, and e) other forms agreed by both parties. Compensation is given as recognition, respect, and protection of human rights (Sumardjono, 2006). Therefore, giving compensation should not cause damaging effects for the landowner. More importantly, compensation regulated in the Constitution of land acquisition should be separately regulated and implemented through civil law so that the principles of justice and equality in law can be achieved.

Tat \& Bagshaw (2014) in analyzing land conflicts in Cambodia states that the basis for the group and individual debate and clashes is related to the conception of economic land concessions (ELCs) which have various implications for land and development. More specifically in analyzing peasants' strategies in Cambodia on land grabbing Verkoren \& Ngin (2017) stated that social networks and collective action have an important meaning in the identity politics of farmers in response to land grabbing. As is the case in this study, which highlights the important function of land for individuals and families with land acquisition for public purposes which sometimes raises disputes, Akin (2017) also explains that the main obstacle to justice at this time is related to land disputes that have ties. socio-culture and economy for the lower classes with the interests of the state or corporation.

In analyzing land disputes in Morocco, Bouzidi et al. (2020) focus on power relations in land disputes in rural areas that affect public policy and farmer confidence. In the context of problem-solving, Patri et al. (2020) stated the possibility of using peaceful means to deal with land disputes through Alternative Dispute Resolution (ADR) in rural Bangladesh. Home (2020) states that the need for shared values in resolving land disputes in sub-Saharan Africa is related to the development and use rights for small groups, the traditional authority, and customary societies as well as development rights by the state or through concessions to developers and corporations, as well as the possibility of settlement through peaceful solutions. Several other studies also highlight legal and administrative processes as well as socio-political dimensions as solutions for peaceful land dispute resolution in various countries (Kobusingye et al., 2016; Santiago, 2017; Unruh, 2001; Rose, 1992; Childs, 2001; Yannakakis, 2008; Sakai, 2002).

\section{CONCLUSIONS}

The findings showed that development carried out by the nation for public welfare is a goal that must be achieved and supported regardless of the dispute/conflict caused by a semantic problem on the definition of public interest, apparatus/executor of land acquisition, and public reluctance in giving their land leading to the form and amount of compensation. Thus, legal certainty over the public right of land must also be protected as stated in the national constitution. Moreover, the land acquisition must be carried out by giving appreciation, protection over human rights, and common interest - including the right to achieve welfare for a better life.

The novelty of this study lies in the exploration of legal concepts in land acquisition for public purposes. The novelty of the study lies fundamentally in the idea of referring to the activity of providing land by providing appropriate and fair compensation to entitled parties. Theoretically, this study demonstrates that this land acquisition is a manifestation of the nation's responsibility which aims to create public welfare through the construction of public facilities as stipulated in the constitution. Practically, in the process, land acquisition needs to involve two parties: the landowner 
and the party who needs the land where the landlord is the community, the nation (institution) is the party who needs the land. This study contributes to emphasizing that it is necessary to provide land for the benefit of the constitutional and beneficial for both parties through land acquisition to realize community welfare as mandated in the constitution.

\section{REFERENCES}

Agrarian Reform Consortium. (2014). Catatan Akhir Tahun 2014: Membenahi Masalah Agraria, Prioritas Kerja Jokowi-JK Pada 2015. Retrieved from http://kpa.or.id/assets/uploads/ files/publikasi/e5113-catatan-akhir-tahun-kpa_2014.pdf.

Agrarian Reform Consortium. (2016). Catatan Akhir Tahun 2016: Liberalisasi Agraria Diperhebat, Reforma Agraria Dibelokkan. Retrieved form http://kpa.or.id/assets/uploads/ files/publikasi/703f7-laporan-akhir-tahun-2016.pdf.

Agrarian Reform Consortium. (2017).Catatan Akhir Tahun 2017: Reforma Agraria di Bawah Bayang Investasi, Gaung Besar di Pinggiran Jalan. Retrieved from http://kpa.or.id/publikasi/ baca/laporan/25/Catahu_2017:_Reforma_Agraria_di_Bawa h_Bayang_Investasi_Gaung_Besar_di_Pinggiran_Jalan/.

Akin, J. (2017). Arresting the Village-to-Prison Pipeline: Mandatory Criminal ADR as a Traditional Justice Strategy. Ga. J. Int'l \& Comp. L., 46, 151.

Bouzidi, Z., Faysse, N., Kuper, M., \& Billaud, J. P. (2020). Investigating the invisible roots of a prevailing narrative of farmers' failed collective action in Morocco. The Journal of North African Studies, 25(3), 342-362. https://doi.org/10.1080/13629387.2018.1563492

Childs, G. (2001). Demographic dimensions of an intervillage land dispute in Nubri, Nepal. American Anthropologist, 103(4), 1096-1113 https://doi.org/10.1525/aa.2001.103.4.1096

Erwiningsih, W. (2009). Hak menguasai negara atas tanah. Yogyakarta: Universitas Islam Indonesia.

Friedman, L. M. (1975). The legal system: A social science perspective. New York: Russell Sage Foundation.

Home, R. (2020). Land dispute resolution and the right to development in Africa. Journal for Juridical Science, 45(1), 72-92. https://doi.org/10.18820/24150517/JJS45.i1.4

Kobusingye, D. N., Van Leeuwen, M., \& Van Dijk, H. (2016). Where do I report my land dispute? The impact of institutional proliferation on land governance in post-conflict Northern Uganda. The Journal of Legal Pluralism and Unofficial Law, 48(2), 238-255. https://doi.org/10.1080/07329113.2016.1195673

Notonagoro, N. (1988). Pancasila Dasar Falsafah Negara. Jakarta: Bina Aksara.
Patoari, M. M. H., Nor, A. H. M., Awang, M. N. B., Chowdhury, A. H., \& Talukder, J. (2020). Legal and Administrative Challenges of Alternative Dispute Resolution (ADR) as a Peaceful Means of Resolving the Land Dispute in the Rural Areas of Bangladesh. Beijing Law Review, 11(02), 415. https://doi.org/10.4236/blr.2020.112026

Poerbopranoto, K. (1987). Sistem Pemerintahan Demokrasi. Bandung: Eresco.

Ritzer, G., \& Stepnisky, J. (2017). Modern sociological theory. Thousand Oaks: Sage publications.

Rose, L. L. (1992). The politics of harmony: Land dispute strategies in Swaziland (Vol. 69). Cambridge University Press. https://doi.org/10.1017/CBO9780511558139

Rousseau, J. J. (1997) [1754]. Discourse on the Origin of Inequality. In Victor Gourevitch (ed.), Rousseau: The Discourses and Other Early Political Writings. Cambridge: Cambridge University Press.

Sakai, M. (2002). Land dispute resolution in the political reform at the time of decentralization in Indonesia. Antropologi Indonesia, $68,40-56$

Santiago, F. (2017). A Legal Perspective of the Law Enforcement of Land Dispute. European Research Studies, 20(4B), 578-587. https://doi.org/10.35808/ersj/912

Sumardjono, M. S. (2006). Kebijakan pertanahan: antara regulasi dan implementasi. Jakarta: Penerbit Buku Kompas.

Sumardjono, M. S. (2008). Tanah Dalam Perspektif Hak EkonomiSosial dan Budaya. Jakarta: Penerbit Buku Kompas.

Tat, P., \& Bagshaw, D. M. (2014). A search for justice and rights in land dispute resolution in Cambodia. Conflict Resolution Quarterly, 32(2), 203-229. https://doi.org/10.1002/crq.21108

Tauchid, M. (2011). Masalah agraria sebagai masalah penghidupan dan kemakmuran rakyat Indonesia. Semarang: Yayasan Bina Desa.

Unruh, J. D. (2001). Postwar land dispute resolution: land tenure and the peace process in Mozambique. International Journal on World Peace, 3-29.

https://doi.org/10.1080/1367886022000016901

Usman, R. (2003). Pilihan Penyelesaian Sengketa di luar pengadilan. Bandung: Citra Aditya Bakti.

Van Wijk, H. D. (1976). Hoofdstukken Van Administratief Recht Gravenhage: VUGA Uitgeverij.

Verkoren, W., \& Ngin, C. (2017). Organizing against land grabbing in Cambodia: exploring missing links. Development and Change, 48(6), 1336-1361. https://doi.org/10.1111/dech.12346

Von Schmid, J. (1954). Grote denkers over de moraal.Tijdschrift Voor Filosofie, 16(1):127.

Wiradi, G. (2009). Metodologi studi agraria: karya terpilih Gunawan Wiradi, Shohibuddin, M. (Ed.). Bogor: Sajogyo Institute.

Yannakakis, Y. (2008). Witnesses, spatial practices, and a land dispute in colonial Oaxaca. The Americas, 65(2), 161-192. https://doi.org/10.1353/tam.0.0031

Received on 07-11-2020

\section{DOI: https://doi.org/10.6000/1929-4409.2021.10.39}

(C) 2021 Wahanisa et al.; Licensee Lifescience Global.

This is an open access article licensed under the terms of the Creative Commons Attribution Non-Commercial License (http://creativecommons.org/licenses/by-nc/3.0/) which permits unrestricted, non-commercial use, distribution and reproduction in any medium, provided the work is properly cited. 